\title{
ChemComm
}

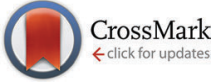

Cite this: Chem. Commun., 2015, 51, 4109

Received 21st November 2014, Accepted 4th February 2015

DOI: $10.1039 / c 4 c c 09304 f$

www.rsc.org/chemcomm

\section{Triphenylarsonium-functionalised gold nanoparticles: potential nanocarriers for intracellular therapeutics $\uparrow$}

\author{
Nikhil Lalwani, ${ }^{a}$ Yu-Su Chen, ${ }^{a}$ Gemma Brooke, ${ }^{a}$ Neil A. Cross, ${ }^{a}$ David W. Allen, ${ }^{a}$ \\ Alan Reynolds, ${ }^{b}$ Jesús Ojeda, ${ }^{b}$ Graham J. Tizzard, ${ }^{c}$ Simon J. Coles ${ }^{c}$ and \\ Neil Bricklebank ${ }^{*^{a}}$
}

\begin{abstract}
Two new triphenylarsonium alkylthiolate precursors, a thiosulfate zwitterion and a thioacetate salt, have been structurally characterised and their cytotoxicity evaluated against PC3 cells. The arsonium compounds have been used to prepare gold nanoparticles decorated with triphenylarsonium groups.
\end{abstract}

Arsenic has attracted the attention of scientists for centuries and its compounds have a variety of applications ranging from electronic and semiconductor materials ${ }^{1}$ to organic reagents, arsonium ylides finding utility in the Wittig reaction. ${ }^{2}$ Historically, arsenic compounds have been widely investigated for their medicinal properties although interest declined as greater understanding of their toxicity became apparent. ${ }^{3,4}$ Generally inorganic $\operatorname{As}(\mathrm{III})$ and $\mathrm{As}(\mathrm{v})$ species are highly toxic, whereas organic arsenic compounds are significantly less toxic. ${ }^{1,5}$ More recently there has been a resurgence of interest in the medicinal properties of arsenic compounds, including the use of arsenic trioxide and organic arsenic derivatives as treatments for leukaemia and other cancers, ${ }^{1,3,4}$ the characterisation of an arsenic trioxide analogue of cisplatin, ${ }^{6}$ and the observation that ${ }^{72} \mathrm{As}$ and ${ }^{74} \mathrm{As}$ radiopharmaceuticals could be useful in positron emission tomography (PET). ${ }^{1}$

The chemistry of arsenic is broadly similar to that of phosphorus, and organic phosphonium salts are known to act as lipophilic cations that are preferentially accumulated in the mitochondria of cells. ${ }^{7}$ Similarly, arsonium cations are also lipophilic and lipophosphoramidate derivatives containing arsonium head-groups $(\mathbf{1})^{8}$ have been studied as gene delivery systems, and ${ }^{64} \mathrm{Cu}$-labelled complexes of 1,4,7,10-tetraazacyclododecane-4,7,10-triacetic

\footnotetext{
${ }^{a}$ Biomedical Research Centre, Sheffield Hallam University, City Campus, Sheffield S1 1WB, UK. E-mail: n.bricklebank@shu.ac.uk

${ }^{b}$ Experimental Techniques Centre, Brunel University, Kingston Lane, Uxbridge, Middlesex, UB8 3PH, UK

${ }^{c}$ EPSRC National Crystallography Service, School of Chemistry,

University of Southampton, Southampton, SO17 1BJ, UK

$\dagger$ Electronic supplementary information (ESI) available. CCDC 1020083 and 1020084. For ESI and crystallographic data in CIF or other electronic format see DOI: $10.1039 / \mathrm{c} 4 \mathrm{cc} 09304 \mathrm{f}$
}

acid-conjugated triphenylarsonium cations (2) have been found to act as tumour-selective PET imaging agents. ${ }^{9}$ Phosphonium species have been found to be extremely valuable for mitochondria-targeted therapeutics and diagnostics. Mitochondrial dysfunction is associated with a number of disorders and there is increasing awareness of the importance of targeting drugs to this organelle. ${ }^{7}$ Recent work has demonstrated the potential of combining phosphonium compounds with nanotechnological approaches to traffic pharmaceutical and diagnostic moieties into mitochondria. ${ }^{10}$ For example, incorporation of phosphonium groups into the lipid bilayer of liposomes, ${ }^{11}$ or onto the surface of dendrimers ${ }^{12}$ and polymer nanoparticles ${ }^{13}$ facilitates their preferential uptake by mitochondria. We have prepared phosphoniumfunctionalised gold nanoparticles ${ }^{14-16}$ which are accumulated by cells and shown by TEM to be localised in the mitochondria. ${ }^{17}$ Inspired by the success of arsonium systems such as $\mathbf{1}$ and $\mathbf{2}$ we decided to broaden the scope of our studies to include triphenylarsonium compounds and herein report our preliminary results on the biological properties of triphenylarsonium alkylthiosulfate zwitterions (3) and salts (4) and their application in the synthesis of triphenylarsonium-functionalised gold nanoparticles (AuNPs).

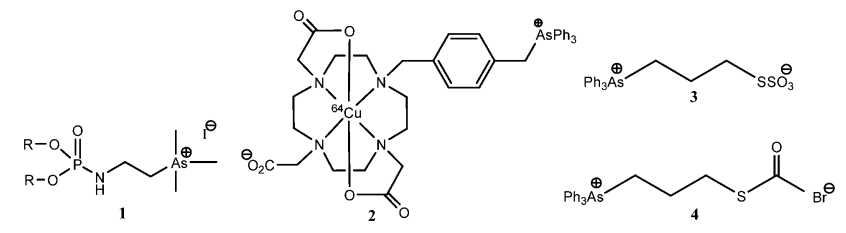

The synthesis of $\mathbf{3}, \mathbf{4}$ and the triphenylarsoniumalkylthiolatefunctionalised AuNPs are described in the ESI. $\dagger$ The structures of $\mathbf{3}$ and $\mathbf{4}$ were confirmed by X-ray crystallography. Perhaps surprisingly, the structures of few organic thiosulfate zwitterions have been reported. ${ }^{18}$ Both compounds display the expected tetrahedral geometry around the arsenic atoms with mean $\mathrm{C}-\mathrm{As}-\mathrm{C}$ bond angles of $109.5(2)^{\circ}$ in 3 and 109.46(11) $)^{\circ}$ in 4 . In zwitterion 3 (Fig. 1), the S-O bonds in the thiosulfate group are similar with a mean length of $1.447(4) \AA$, indicative of multiple bond character, and that the negative charge is delocalised over the 


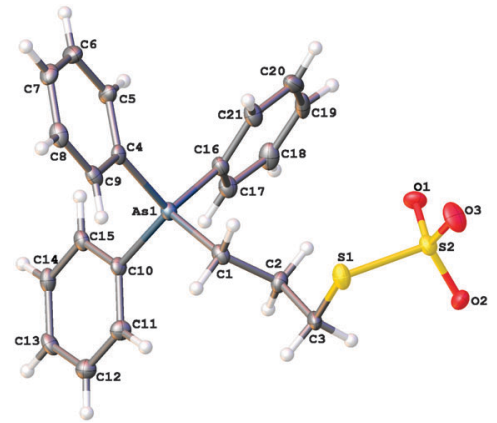

Fig. 1 Molecular structure of zwitterion 3.

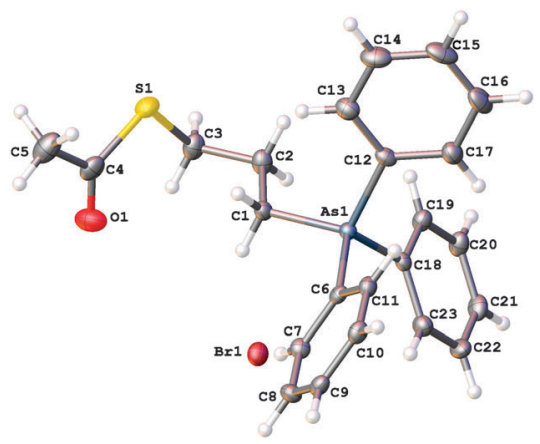

Fig. 2 Molecular structure of thioacetate salt 4

entire sulfate group. The mean $\mathrm{O}-\mathrm{S}-\mathrm{O}$ angle $\left[113.8(2)^{\circ}\right]$ is consistent with those in other thiosulfate ions. ${ }^{18}$ The S-S bond length $[2.1081(18) \AA]$, is slightly shorter than that of the corresponding phosphonium compound $[2.1117(9) \AA]$ longer than the $\mathrm{S}-\mathrm{S}$ bond in ionic thiosulfate ions such as $\mathrm{Me}_{2} \mathrm{HN}\left(\mathrm{CH}_{2} \mathrm{~S}_{2} \mathrm{O}_{3}\right)_{2}{ }^{-} \mathrm{Na}^{+} .^{18}$ Within the crystal lattice the zwitterions pack fairly loosely, held together by hydrogen-bonding interactions between the sulfate oxygens and the phenyl hydrogens, but there is no close interaction between the arsonium and the thiosulfate moieties. The bond lengths and angles of the thioacetate group in salt 4 (Fig. 2), are as expected. The molecular packing shows no significant interactions between the arsonium centre and the bromide anion or between the bromide and the carbonyl group.

In order to evaluate the efficacy of the triphenylarsoniumfunctionalised AuNPs as cellular transport systems we first screened the parent arsonium compounds $\mathbf{3}$ and $\mathbf{4}$ against the PC3 prostate cancer cell line. Cell viability was assessed using MTT and CellTitre-Glo ${ }^{\mathbb{R}}$ assays (Fig. 3). MTT measures mitochondrial activity to determine the in vitro cytotoxic effects of chemical entities. The results showed 3 and 4 to have $\mathrm{IC}_{50}$ values of $75 \mu \mathrm{M}$ and $72 \mu \mathrm{M}$, respectively, after 72 hours. These values compare very favourably with those of phosphonium compounds, a large number of which have been screened using MTT against PC3 cells, and which displayed $\mathrm{IC}_{50}$ values in the range 0.4-5 $\mu \mathrm{M} .{ }^{19}$ These results are also in accordance with cellular toxicity data for lipophosphoramidate derivatives, where phosphonium compounds show greater cytotoxicity than the corresponding arsonium compounds. ${ }^{8}$ We also used the

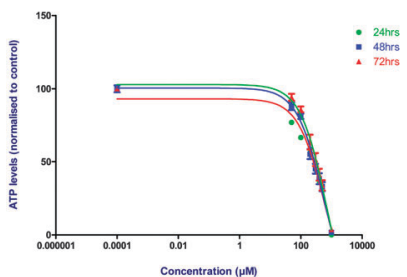

(a)

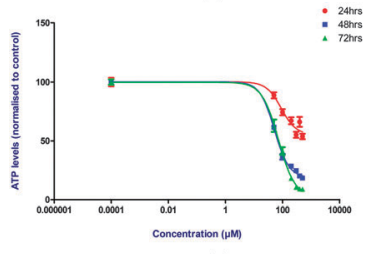

(c)

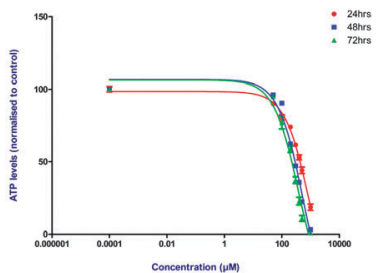

(b)

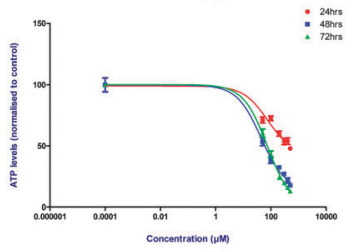

(d)
Fig. 3 Cell viability studies of triphenylarsonium derivatives 3 and 4: (a) Cell Titre Glo assay of zwitterion 3; (b) Cell Titre Glo assay of thioacetate salt 4; (c) MTT assay of 3; (d) MTT assay of $\mathbf{4}$

CellTitre-Glo ${ }^{\mathbb{R}}$ assay to confirm the MTT cytotoxicity data. This uses luminescence to determine the number of viable cells based on a quantification of ATP levels. The data showed a similar trend to that determined using MTT.

The cytotoxicity of arsenic compounds is crucially dependent on the nature and oxidation state of the species. Inorganic compounds, such as arsenite and arsenate, show acute toxicity; for example, the $\mathrm{IC}_{50}$ of sodium arsenate was reported as $6 \mu \mathrm{M}^{20}$ In contrast, the organic derivative arsenobetaine, $\mathrm{Me}_{3} \mathrm{As}^{+} \mathrm{CH}_{2} \mathrm{CO}_{2}{ }^{-}$, an important metabolite of arsenic which is widely distributed in marine ecosystems and found in comparatively high levels in seafood, is reported to have no toxic effects and was found to significantly enhance the cell viability of bone marrow cells in vitro in a concentration-dependent manner. ${ }^{20}$

Phosphonioalkylthiosulfate zwitterions, ${ }^{15}$ and phosphonium alkylthioacetate salts, ${ }^{16}$ are known to act as 'masked thiolates' and under reductive conditions cleavage of the thiosulfate S-S or thioacetate $\mathrm{S}-\mathrm{C}$ bonds, respectively, takes place, generating phosphonioalkylthiolate zwitterions that can coordinate to the surface of gold films.

We have exploited this chemistry to generate water-soluble cationic gold nanoparticles functionalised with alkylthiolate ligands bearing phosphonium head-groups. We have now extended this approach to the analogous arsonium compounds. Reduction of tetrachloroaurate salts in situ with sodium borohydride in the presence of $\mathbf{3}$ or $\mathbf{4}$ in a biphasic water/dichloromethane mixture yields the triphenylarsonium-capped AuNPs. Recent work has reported rare examples of the coordination chemistry of tertiary arsine ligands bearing pendant thiolate groups towards $\mathrm{Ni}(\mathrm{II}), \mathrm{Pt}(\mathrm{II})$ and $\mathrm{Pd}(\mathrm{II}) .{ }^{21}$ However, to the best of our knowledge, there are no reports of the coordination chemistry of triorganoarsonium thiolate species or of the use of tertiary arsines or arsonium compounds as capping ligands in the formation of functionalised nanoparticles, although nanoscale liposomes or nanobins, composed of lipids and metal salts, have been used to encapsulate and stabilise arsenic trioxide in order to extend the clinical utility of this compound. ${ }^{22}$ 

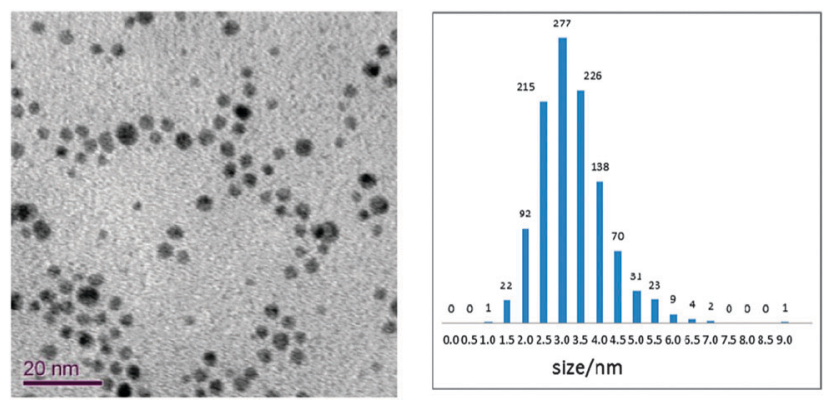

Fig. 4 TEM image of arsonium-AuNP derived from zwitterion 3 and associated particle size histogram.

The triphenylarsonium-AuNPs can be purified by extraction with dichloromethane followed by freeze drying. The UV-Vis spectrum of a typical sample of arsonium-capped nanoparticles shows an absorption band with $\lambda_{\max }$ of $520 \mathrm{~nm}$. High resolution TEM analysis of the AuNPs derived from the thiosulfate zwitterions is shown in Fig. 4, and revealed the AuNPs to have spherical shapes. Size distribution analysis of 1000 particles using Abel imaging software revealed a mean diameter of $2.7 \pm 0.9 \mathrm{~nm}$. This compares favourably with the corresponding phosphonium-capped AuNPs which have an average particle size of $3.0 \pm 1.2 \mathrm{~nm}$. Wide scan XPS spectra of the arsonium-AuNPs contained signals due to $\mathrm{Au}, \mathrm{S}, \mathrm{As}$ and $\mathrm{C}$, with the gold displaying the characteristic doublet for $\mathrm{Au}\left(4 \mathrm{f}_{7 / 2}\right)$ and $\mathrm{Au}\left(4 \mathrm{f}_{5 / 2}\right)$ with binding energies of $c a$. 83.9 and $87.5 \mathrm{eV}$ respectively, indicative of the presence of $\mathrm{Au}(0) .{ }^{14}$ Research is now ongoing to understand the cellular uptake of the triphenylarsonium-AuNPs and confirm their presence inside the cells using TEM to realise their potential intracellular transport properties.

We are grateful to Sheffield Hallam University and Indian Institute of Science (NL) for financial support.

\section{Notes and references}

1 A. Mudhoo, S. K. Sharma, V. K. Garg and C.-H. Tseng, Crit. Rev. Environ. Sci. Technol., 2011, 41, 435-519.

2 H. S. He, C. W. Y. Chung, T. Y. S. But and P. H. Toy, Tetrahedron, 2005, 61, 1385-1405.

3 S.-J. Chen, G.-B. Zhou, X.-W. Zhang, J.-H. Mao, H. de Thé and Z. Chen, Blood, 2011, 117, 6425-6437.

4 E. P. Swindell, P. L. Hankins, H. Chen, Đ. U. Miodragović and T. V. O'Halloran, Inorg. Chem., 2013, 52, 12292-12304.
5 K. Jomova, Z. Jenisova, M. Festerova, S. Baros, J. Liska, D. Hudecova, C. J. Rhodes and M. Valko, J. Appl. Toxicol., 2011, 31, 95-107.

6 Đ. U. Miodragović, J. A. Quentzel, J. W. Kurutz, C. L. Stern, R. W. Ahn, I. Kandela, A. Mazar and T. V. O'Halloran, Angew. Chem., Int. Ed., 2013, 52, 10749-10752.

7 (a) A. T. Hoyle, J. E. Davoren, P. Wipf, M. P. Fink and V. E. Kagan, Acc. Chem. Res., 2008, 41, 87-97; (b) V. Weissig, Pharm. Res., 2011, 28, 2657-2668.

8 (a) E. Picquet, K. Le Ny, P. Delépine, T. Montier, J.-J. Yaouanc, D. Cartier, H. des Abbayes, C. Férec and J.-C. Clément, Bioconjugate Chem., 2005, 16, 1051-1053; (b) T. Le Gall, D. Loizeau, E. Picquet, N. Carmoy, J.-J. Yaouanc, L. Burel-Deschamps, P. Delépine, P. Giamarchi, P.-A. Jaffrès, P. Lehn and T. Montier, J. Med. Chem., 2010, 53, 1496-1508; (c) M. Berchel, T. Le Gall, H. Couthon-Gourvès, J.-P. Haelters, T. Montier, P. Midoux, P. Lehn and P.-A. Jaffrès, Biochimie, 2012, 94, 33-41.

9 J. Wang, C. T. Yang, Y. S. Kim, S. G. Sreerama, Q. Cao, Z. Li, Z. He, X. Chen and S. Liu, J. Med. Chem., 2007, 50, 5057-5069.

10 S. S. Malhi and R. S. R. Murthy, Expert Opin. Drug Delivery, 2012, 9, 909-935.

11 (a) S. V. Boddapati, G. G. M. D'Souza, S. Erdogan, V. P. Torchilin and V. Weissig, Nano Lett., 2008, 8, 2559-2563; (b) S. Biswas, N. S. Dodwadkar, P. P. Deshpande and V. P. Torchilin, J. Controlled Release, 2012, 159, 393-402; (c) S. V. Boddapati, P. Tongcharoensirikul, R. N. Hanson, G. G. M. D'Souza, V. P. Torchilin and V. Weissig, J. Liposome Res., 2005, 15, 49-58.

12 S. Biswas, N. S. Dodwadkar, A. Piroyan and V. P. Torchilin, Biomaterials, 2012, 33, 4773-4782.

13 X.-H. Wang, H.-S. Peng, L. Yang, F.-T. You, F. Teng, A.-W. Tang, F.-J. Zhang and X.-H. Li, J. Mater. Chem. B, 2013, 1, 5143-5152.

14 Y. Ju-Nam, Y.-S. Chen, J. J. Ojeda, D. W. Allen, N. A. Cross, P. H. E. Gardiner and N. Bricklebank, RSC Adv., 2012, 2, 10345-10351.

15 Y. Ju-Nam, N. Bricklebank, D. W. Allen, P. H. E. Gardiner, M. E. Light and M. B. Hursthouse, Org. Biomol. Chem., 2006, 4, 4345-4351.

16 Y. Ju-Nam, D. W. Allen, P. H. E. Gardiner and N. Bricklebank, J. Organomet. Chem., 2008, 693, 3504-3508.

17 Y.-S. Chen, PhD thesis, Sheffield Hallam University, 2014.

18 J.-X. Chen, Q.-F. Xu, Y. Zhang, S. M. Zain, S. W. Ng and P.-P. Lang, Acta Crystallogr., Sect. C: Cryst. Struct. Commun., 2004, 60, 0572-0574.

19 M. Millard, D. Pathania, Y. Shabaik, L. Taheri, J. Deng and N. Neamati, PLoS One, 2010, 5, e13131.

20 T. Sakurai and K. Fujiwara, Br. J. Pharmacol., 2001, 132, 143-150.

21 (a) A. Hildebrand, I. Sárosi, P. Lönnecke, L. Silaghi-Dumitrescu, M. B. Sárosi, I. Silaghi-Dumitrescu and E. Hey-Hawkins, Inorg. Chem., 2012, 51, 7125-7133; (b) A.-M. Valean, S. Gomex-Ruiz, L. SilaghiDumitrescu and E. Hey-Hawkins, Z. Anorg. Chem., 2013, 639, 1220-1226.

22 (a) R. W. Ahn, S. L. Barrett, M. R. Raja, J. K. Jozefik, L. Spaho, H. Chen, A. P. Mazar, M. J. Avram, J. N. Winter, L. I. Gordon, L. D. Shea, T. V. O'Halloran and T. K. Woodruff, PLoS One, 2013, 8, e58491; (b) S.-M. Lee, O.-S. Lee, T. V. O'Halloran, G. C. Schatz and S. T. Nguyen, ACS Nano, 2011, 3961-3969; (c) H. Chen, S. Pazicni, N. L. Krett, R. W. Ahn, J. Penner-Hahn, S. T. Rosen and T. V. O'Halloran, Angew. Chem., Int. Ed., 2009, 121, 9459-9463; (d) H. Chen, R. C. MacDonald, S. Li, N. L. Krett, S. T. Rosen and T. V. O'Halloran, J. Am. Chem. Soc., 2006, 128, 13348-13349. 